\title{
HUBUNGAN ANTARA PEMAHAMAN UNSUR KEBAHASAAN DAN SIKAP TERHADAP BAHASA INDONESIA DENGAN KOMPETENSI MENULIS KARYA ILMIAH MAHASISWA
}

\author{
Rian Apriliani, Sarwiji Suwandi, Budhi Setiawan \\ Program Studi S2 Pendidikan Bahasa Indonesia \\ Fakultas Keguruan dan Ilmu Pendidikan \\ Universitas Sebelas Maret \\ aprilia240492@student.uns.ac.id
}

\begin{abstract}
Abstrak
Penelitian ini bertujuan untuk mengidentifikasi kemunculan korelasi antara unsur-unsur komprehensi berbahasa dan sikap terhadap bahasa Indonesia melalui kompetensi menulis. Penelitian ini dilaksanakan pada mahasiswa Program Studi Pendidikan MIPA, FKIP UNS dari bulan Juli 2015 dengan menerapkan metode survey sebagai alat untuk studi korelasional. Populasi data mencakup semua mahasiswa Prodi PMIPA yang mengikuti kuliah bahasa Indonesia. Sampel penelitian adalah berupa karya-karya dari 70 orang mahasiswa yang dikumpulkan dengan teknik sampling acak. Data dikumpulkan dengan mengadakan tes kompetensi pada kemampuan menulis, tes komprehensi unsur-unsur kebahasaan, dan kuesioner mengenai sikap terhadap bahasa Indonesia. Setelah itu, data dianalisis secara statistic dengan multiple analyses dan analisis korelasi. Hasil penelitian ini mengindikasikan bahwa 1) ada hubungan antara pemahaman unsur kebahasaan dan kompetensi menulis karya ilmiah.; 2) ada hubungan antara sikap terhadap bahasa Indonesia dan kompetensi menulis karya ilmiah; 3) ada hubungan antara pemahaman unsur kebahasaan dan sikap terhadap bahasa Indonesia secara bersama-sama dengan kompetensi menulis karya ilmiah.
\end{abstract}

Kata Kunci: penguasaan elemen-elemen bahasa, sikap terhadap bahasa Indonesia, penulisan karya ilmiah

\begin{abstract}
This study aims at investigating the presence of correlation between comprehension of language elements and attitude towards Indonesian language with scientific paper writing competence. This research was conducted on the students of MIPA-FKIP UNS from July to November 2015 by employing survey method as a tool of correlational study. The population included all students of PMIPA-FKIP UNS attending Indonesian language course and the research samples were 70 students, gathered using cluster random sampling technique. The research data were collected with composition test of scientific paper writing, test of comprehension of language elements and questionnaires on attitude towards Indonesian language. Afterwards, the data were statistically analyzed using simple and multiple regression analyses and correlation analysis. The research results indicate that 1) there is a positive and significant correlation between comprehension of language elements and scientific paper writing competence; 2) there is a positive and significant correlation between attitude towards Indonesian language and scientific paper writing competence; and 3) there is a positive and significant correlation between comprehension of language el-
\end{abstract}


ements and attitude towards Indonesian language along with scientific paper writing competence.

Keywords: mastery of language elements, attitude towards Indonesian language, scientific paper writing

\section{Pendahuluan}

Kompetensi menulis ilmiah merupakan salah satu kompetensi dasar yang harus dimiliki oleh setiap mahasiswa. Kompetensi menulis termasuk dalam kompetensi yang sukar dan kompleks karena membutuhkan kemampuan yang berkaitan dengan keterampilan gramatikal, penuangan isi, keterampilan stilistika, keterampilan mekanis, serta keterampilan memutuskan (Heaton dalam Slamet, 2009:96-98). Karya ilmiah bagi mahasiswa S1 dapat digunakan sebagai sarana untuk mengembangkan serta mengenali kemampuan dan potensi dirinya.

Penelitian tentang kemampuan menulis sebelumnya pernah dilakukan oleh Ahmadian, dkk. (2013). Penelitian tentang pengaruh kritik guru dan kritik teman sebaya terhadap kemampuan menulis esai pada mahasiswa tersebut menunjukkan bahwa umpan balik teman sejawat tidak lebih efektif daripada umpan balik guru dalam membantu peserta didik meningkatkan kemampuan menulis mereka, terutama menulis esai.

Kompetensi menulis ilmiah berkaitan erat dengan kepandaian seseorang. Kepandaian seseorang dapat diukur dari tulisan ilmiah yang dihasilkannya. Hal ini karena menulis ilmiah merupakan proses kreatif yang melibatkan unsur kompleks, baik kognitif maupun psikomotor. Hal tersebut diperkuat dengan penelitian yang dilakukan Singh dan Rajalingan (2012) yang mengindikasikan bahwa memiliki tingkat kepandian menulis dan kecakapan menulis yang tinggi dapat menunjukkan hasil kerja responden yang baik. Ini menunjukkan bahwa ada hubungan positif antarvariabel yang diukur, yakni tingkatan kepandaian menulis dan keahlian menulis yang mengindikasikan hasil tulisan yang lebih baik.

Penelitian serupa juga dilakukan oleh
Jahin (2012) yang bertujuan untuk mengetahui tingkat kemampuan menulis esai pada calon guru EFL. Hasil analisis data menunjukkan dampak positif dari tinjauan rekan sejawat dalam kelompok peserta eksperimen terhadap kepandaian menulis dan kemampuan menulis esai.

Bouchman, dkk. (2012) melakukan penelitian pada siswa di Kanada yang dibidik dari sudut pandang hubungan antara penggunaan bahasanya dan performasi ketrampilan menulis karya ilmiah. Penelitian ini menunjukkan adanya hubungan positif antara keduanya. Siswa yang berbicara menggunakan bahasa ibu menghabiskan paling sedikit waktu untuk menulis karya ilmiah bila dibandingkan dengan siswa multibahasa dan siswa ber-anglophone yang menghabiskan paling banyak waktu untuk menulis karya mereka.

Penelitian lain dilakukan oleh Wardani, dkk. (2013) yang mengungkapkan bahwa siswa SMAN 1 Singaraja menunjukkan frekuensi campur kode dan interferensi yang tinggi. Hal ini yang kemudian mengakibatkan aspek sikap bahasa siswa terhadap bahasa Indonesia menjadi negatif. Apabila sikap bahasa siswa negatif, hal tersebut akan berpengaruh dalam kegiatan pembelajaran pembelajaran bahasa mereka. Hal tersebut dikarenakan sikap bahasa merupakan faktor penentu keberhasilan mempelajari bahasa (dalam hal ini adalah bahasa Indonesia). Berdasarkan hasil penelitian tersebut, kompetensi menulis tidak terlepas dari sikap terhadap bahasa yang dimiliki oleh masing-masing individu. Aspek lain yang memiliki hubungan dengan kompetensi menulis karya ilmiah adalah adanya sikap bahasa yang baik pada diri penulis. Memiliki rasa cinta dan bangga terhadap bahasa Indonesia juga dapat memberikan pengaruh terhadap pengetahuan mahasiswa. Mahasiswa yang memiliki sikap positif 
terhadap bahasa Indonesia akan terbiasa menggunakan bahasa Indonesia yang baik dan benar, yakni bahasa yang digunakan sesuai dengan norma kemasyarakatan yang berlaku dan sesuai dengan kaidah bahasa Indonesia yang baku.

Teori yang digunakan dalam landasan teoritis ini meliputi: 1) hakikat kompetensi menulis karya ilmiah, 2) hakikat pemahaman unsur kebahasaan, dan 3) hakikat sikap terhadap bahasa Indonesia. Dalman (2014:3) berpendapat bahwa menulis merupakan suatu kegiatan komunikasi berupa penyampaian pesan (informasi) secara tertulis kepada pihak lain dengan menggunakan bahasa tulis sebagai alat atau medianya. Jika menulis dikaitkan dengan kompetensi, Suriamiharja (2011:1) menyatakan bahwa kompetensi menulis merupakan kegiatan melahirkan pikiran dan perasaan dengan tulisan. Kompetensi menulis merupakan kompetensi yang masih dianggap paling sukar untuk dikuasai mahasiswa bila dibandingkan dengan tiga kompetensi berbahasa yang lainnya. Hal tersebut diperkuat oleh pendapat Nurgiyantoro (2014:422) yang menyatakan bahwa kompetensi menulis lebih sulit dikuasai, bahkan oleh penutur asli bahasa yang bersangkutan sekalipun. Kesulitan tersebut disebabkan karena kompetensi menulis menyaratkan pemahaman berbagai unsur, baik unsur di luar kebahasaan maupun unsur dari dalam kebahasaan.

Salah satu produk kompetensi menulis di kalangan akademik adalah karya ilmiah. Suwandi (2011:78) mengungkapkan bahwa karya ilmiah merupakan karya tulis yang mengikuti kaidah dan jalan pikiran yang berlaku dalam ilmu pengetahuan, serta memberikan sumbangan kepada khazanah ilmu pengetahuan di bidang masing-masing. Murtono (2010:13) berpendapat bahwa penulisan karya ilmiah harus memenuhi tiga komponen, yaitu (1) dasar kebahasaan yang meliputi pilihan kata (diksi), gaya bahasa, kalimat yang efektif, dan alinea, (2) organisasi komposisi yang meliputi tema karangan, kerangka karangan, dan pengumpulan data, serta (3) komposisi ilmiah tertulis yang meliputi kutipan, catatan kaki, biografi, dan ejaan.

Kompetensi menulis karya ilmiah adalah kesanggupan atau kemahiran mahasiswa dalam menuangkan pikiran, ide, atau gagasan serta pengalamannya ke dalam bahasa Indonesia yang baik dan benar dan yang diindikatori melalui kesanggupan mereka dalam menuangkan isi gagasan dengan (1) masalah yang dibahas, (2) bahasa yang terorganisasi secara runtut, teratur, dan jelas (koheren dan kohesif), (3) struktur atau pola kalimat yang benar, serta (4) penggunaan diksi atau pilihan kata yang tepat, dan 5) memperhatikan ketepatan ejaan.

Menurut Djojosuroto (2007:137), "kebahasaan" merupakan hal-hal atau masalah-masalah filosofis yang berkaitan dengan analisis makna kata dan hubungan logis antarkata di dalam bahasa.Kemudian Verhaar (2012:9-10) menyatakan bahwa morfologi dan sintaksis bersama-sama lazimnya biasa disebut 'tatabahasa'. Pemahaman pada tataran morfologi, menyangkut pemahaman tentang proses morfologis yang meliputi afiksasi, redulikasi, dan nosi. Pada tataran sintaksis dengan kedua jenis pemahaman dan penyusunan frasa, klausa, dan kalimat. Dalam menulis karya ilmiah, tataran gramatika atau tata bahasalah yang sangat berperan, sebab tataran gramatika merupakan salah satu unsur terpenting dalam menentukan kualitas kompetensi menulis karya ilmiah mahasiswa. Hal ini berpijak pada sifat penting karya ilmiah menurut Dwiloka (2005:2) yakni awet, yang artinya dapat dibaca oleh siapa saja, dimana saja, dan kapan saja; untuk itu harus ditulis dengan sebaik-baiknya dan diupayakan tanpa kesalahan.

Yang dimaksud dengan pemahaman unsur kebahasaan dalam penelitian ini adalah kesanggupan atau kemahiran mahasiswa dalam memahami dan menggunakan unsur-unsur kebahasaan untuk kepentingan manuangkan pikiran, ide atau gagasan, serta pengalamannya ke dalam bahasa Indonesia yang baik dan benar.

Menurut Sarwono (2010:201) sikap 
adalah istilah yang mencerminkan rasa senang, tidak senang, atau perasaan biasa-biasa saja (netral) dari seseorang terhadap sesuatu. LaPierre (dalam Azwar, 2013:5) mendefinisikan sikap sebagai suatu pola perilaku, tendensi atau kesiapan antisipatif, predisposisi untuk menyesuaikan diri dalam situasi sosial, atau secara sederhana. sikap adalah respons terhadap stimuli sosial yang telah terkondisikan.

Sikap bahasa merupakan dorongan dari dalam diri individu yang berhubungan dengan proses motif, emosi, presepsi, dan kognisi yang mendasari seseorang dalam bertingkah laku, khususnya dalam objek bahasa (Anderson dalam Sumarsono, 2002:363). Garvin dan Mathiot (dalam Chaer, 2004:152) mengemukakan bahwa sikap bahasa meliputi (1) kesetiaan bahasa, (2) kebanggaan bahasa, dan (3) kesadaran adanya norma bahasa. Rokhman (2013:44) berpendapat bahwa sikap bahasa terdiri atas tiga komponen, yaitu (1) komponen kognitif, (2) komponen afektif, dan (3) komponen konatif. Sikap yang terdiri dari sikap positif dan negarif akan mempengaruhi sikap dan tingkah laku seseorang dalam menggunakan bahasa.

Berdasarkan pendapat ahli di atas, hakikat sikap terhadap bahasa Indonesia didefinisikan sebagai tata kepercayaan yang berhubungan dengan bahasa Indonesia yang relatif berlangsung lama dan memberikan kecenderungan kepada seseorang untuk bertindak dengan cara tertentu yang disukainya. Sikap terhadap bahasa Indonesia adalah respon (tanggapan) yang dapat dilihat dari segi kognitif mengenai gagasan atau proporsi yang menyatakan hubungan antara situasi dan objek sikap dan dari segi afektif mengenai emosi atau perasaan yang muncul bersamaan dengan gagasan; dan serta dari segi perilaku mengenai kesiapan untuk bertindak.

Berpijak dari uraian di atas, tujuan penelitian ini adalah untuk membuktikan ada tidaknya hubungan antara pemahaman unsur kebahasaan dan sikap terhadap bahasa Indonesia dengan kompetensi menulis karya ilmiah, baik secara sederhana maupun ganda.

\section{Metode Penelitian}

Penelitian ini dilaksanakan pada mahasiswa pendidikan MIPA-FKIP UNS. Pelaksanaan penelitian selama 5 bulan dimulai dari Juli-November 2015. Jenis penelitian ini adalah penelitian survai dengan teknik korelasional.

Populasi penelitian ini adalah seluruh mahasiswa MIPA-FKIP UNS yang menempuh mata kuliah bahasa Indonesia dengan jumlah mahasiswa 235. Sampel diambil dari 70 mahasiswa dengan teknik purposive random sampling. Instrumen pengumpulan data yang digunakan berupa tes komposisi menulis karya ilmiah, tes penguasaan unsur kebahasaan, dan angket sikap terhadap bahasa Indonesia.

Validitas tes komposisi menulis karya ilmiah menggunakan validitas konstruk dan reliabilitas dengan reliabilitas ratings. Validitas tes pemahaman unsur kebahasaan menggunakan rumus koefisien korelasi point biserial dan reliabilitas menggunakan rumus KR-20. Validitas angket sikap terhadap bahasa Indonesia menggunakan rumus product moment dan reliabilitas menggunakan rumus Alpha Cronbach. Teknik analisis yang digunakan meliputi uji persyaratan hipotesis dan uji hipotesis. Uji persyaratan meliputi uji normalitas data dan signifikansi, sedangkan uji linearitas meliputi uji F.

\section{Hasil Dan Pembahasan}

Data kompetensi menulis karya ilmiah merupakan skor yang diperoleh melalui tes kompetensi menulis karya ilmiah. Data kompetensi menulis karya ilmiah memiliki skor tertinggi 80 dan skor terendah 53, mean 66,09 ; varians data ini adalah 67,62; simpangan baku sebesar 8,22 ; modus data ini adalah 56; dan median dalam data ini adalah 66. Berdasarkan deskripsi data tersebut, dapat divisualisasikan gambar histogram dan poligon frekuensi data sebagai berikut. 


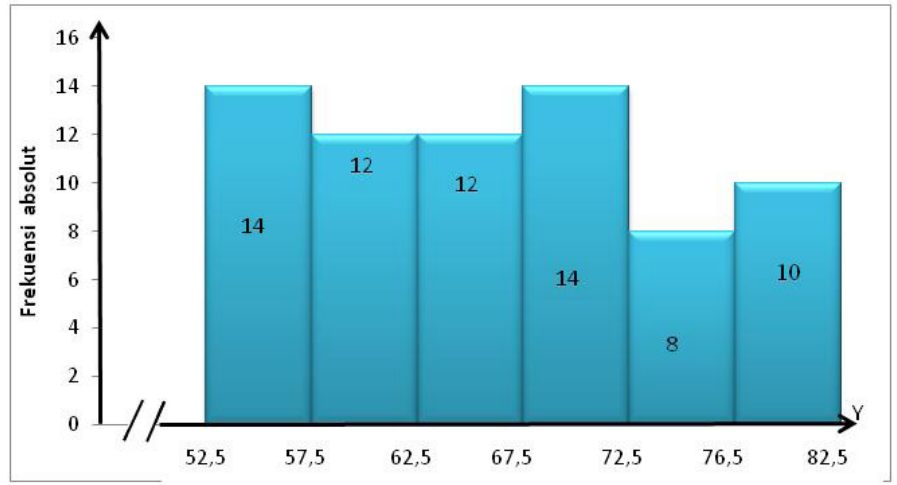

Gambar 1. Histogram dan Poligon Frekuensi Nilai Kompetensi Menulis Karya Ilmiah (Y)

Data pemahaman unsur kebahasaan merupakan skor yang diperoleh melalui tes pemahaman unsur kebahasaan. Data pemahaman unsur kebahasaan memiliki skor tertinggi 35 dan skor terendah 20, mean 27,71; varians data ini adalah 11,77; simpangan baku sebesar 3,43 ; modus data ini adalah 29; dan median dalam data ini adalah 28. Berdasarkan deskripsi data tersebut, dapat divisualisasikan gambar histogram dan poligon frekuensi data sebagai berikut.

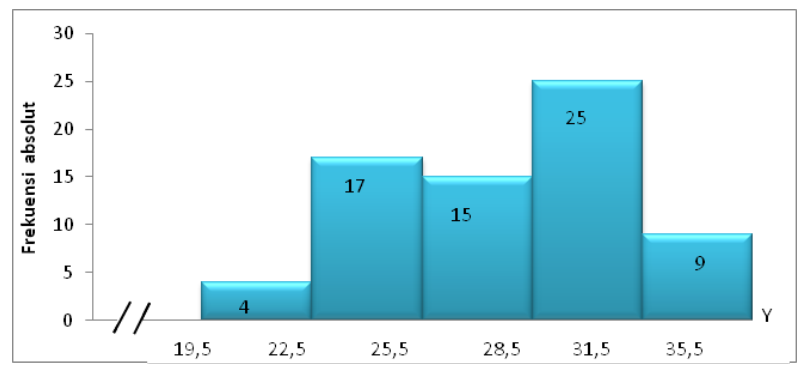

Gambar 2. Histogram dan Poligon Frekuensi Nilai Pemahaman Unsur Kebahasaan $\left(\mathrm{X}_{1}\right)$

Data sikap terhadap bahasa Indonesia merupakan skor yang diperoleh melalui angket terhadap sikap bahasa mahasiswa terhadap bahasa Indonesia. Data sikap terhadap bahasa Indonesia memiliki skor tertinggi 114 dan skor terendah 89, mean 101,46; varians data ini adalah 40,05; simpangan baku sebesar 6,33; modus data ini adalah 101; dan median dalam data ini adalah 101. Berdasarkan deskripsi data tersebut, dapat divisualisasikan gambar histogram dan poligon frekuensi data sebagai berikut.

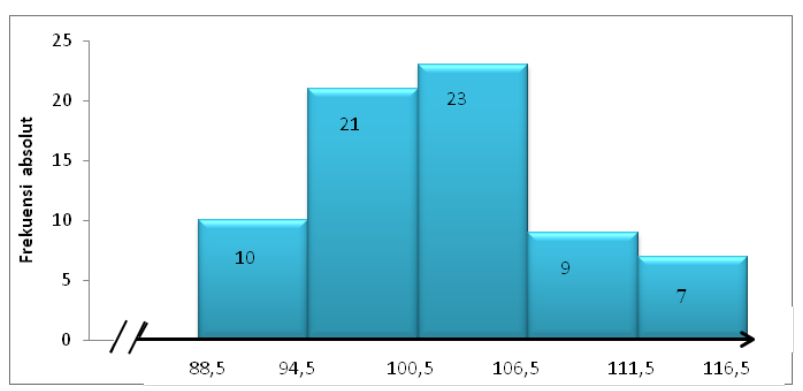

Gambar 3. Histogram dan Poligon Frekuensi Nilai Sikap terhadap Bahasa Indonesia $\left(\mathrm{X}_{2}\right)$

Hasil analisis yang pertama, yaitu uji persyaratan dan uji normalitas. Uji normalitas dari ketiga data menunjukkan bahwa $\mathrm{L}_{\mathrm{o}}$ maksimum $\mathrm{X}_{1}(0,0823), \mathrm{X}_{2}(0,0873)$, dan $\mathrm{Y}^{\circ}$
$(0,0960)<\mathrm{L}_{\mathrm{t}}(0,1059)$ dengan $\mathrm{n}=70$ pada taraf nyata $\alpha=0,05$. Ketiga data tersebut berdistribusi normal. Rangkuman uji normalitas dapat dilihat pada tabel berikut. 
Tabel 1. Rangkuman Hasil Uji Normalitas Data Penelitian

\begin{tabular}{lcll}
\hline Variabel & L0 & $\begin{array}{c}\mathrm{L}_{\mathrm{t}}(\alpha=0,05 \\
\mathrm{n}=70)\end{array}$ & Status \\
\hline $\mathrm{Y}$ & 0,0960 & 0,1059 & Normal \\
$\mathrm{X}_{1}$ & 0,0823 & 0,1059 & Normal \\
$\mathrm{X}_{2}$ & 0,0873 & 0,1059 & Normal \\
\hline
\end{tabular}

Selanjutnya uji linearitas diperoleh, baik dari persamaan regresi $\hat{Y}=21,33+$ $1,61 \mathrm{X}_{1}$ maupun persamaan regresi $\hat{\mathrm{Y}}=$
$16,95+0,48 \mathrm{X}_{2}$ linear. Hasil uji signifikansi dan uji hipotesis bisa dilihat di tabel berikut.

Tabel 2. Rangkuman Hasil Analisis Uji Signifikansi dan Uji Hipotesis

\begin{tabular}{|c|c|c|c|c|}
\hline $\begin{array}{l}\text { Uji dan } \\
\text { Bentuk } \\
\text { Hubungan }\end{array}$ & Uji Signifikansi & $\begin{array}{c}\text { Analisis Regresi dan } \\
\text { Linier Sederhana }\end{array}$ & $\begin{array}{c}\text { Analisis Koe- } \\
\text { fisien Korelasi } \\
\text { Sederhana dan } \\
\text { Ganda }\end{array}$ & Kontribusi \\
\hline $\mathrm{Y}_{\mathrm{X} 1}$ & $\begin{array}{l}\text { Ho: "regresi tidak sig- } \\
\text { nifikan/ ditolak" } \\
(\mathrm{Fo}>\mathrm{Ft})(56,24>3,99) \\
\text { Ha: "regresi signifikan/ } \\
\text { diterima" } \\
\left(\mathrm{F}_{\mathrm{o}}<\mathrm{F}_{\mathrm{t}}\right)(0,77<31,88) \\
\mathbf{t}_{\mathbf{1}} \mathbf{7 , 4}>\mathbf{t}_{\mathbf{t}} \mathbf{1 , 6 7}\end{array}$ & $\hat{Y}=21,33+1,61 X_{1}$ & $\begin{array}{l}\text { Koefisien korelasi } \\
\left(\mathrm{r}_{\mathrm{y} 1}\right) \text { sebesar } 0,67 \\
\text { dengan } t_{\text {tabel }} 1,67\end{array}$ & $\begin{array}{l}\text { 44,89\% ke- } \\
\text { pada Kompe- } \\
\text { tensi Menulis } \\
\text { Karya Ilmiah }\end{array}$ \\
\hline $\mathrm{Y}_{\mathrm{X} 2}$ & $\begin{array}{l}\text { Ho: "regresi tidak sig- } \\
\text { nifikan/ ditolak" } \\
\left(\mathrm{F}_{\mathrm{o}}>\mathrm{F}_{\mathrm{t}}\right)(10,86>3,99) \\
\text { Ha: "regresi signifikan/ } \\
\text { diterima" } \\
\left(\mathrm{F}_{\mathbf{0}}<\mathrm{F}_{\mathrm{t}}\right)(1,17<1,76) \\
\mathbf{t}_{\mathbf{2}} \mathbf{3 , 2 8}>\mathbf{t}_{\mathbf{t}} \mathbf{1 , 6 7}\end{array}$ & $\hat{Y}=16,95+0,48 X_{2}$ & 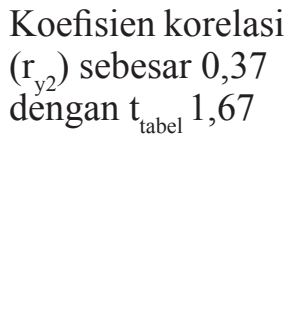 & $\begin{array}{l}\text { 13,69\% ke- } \\
\text { pada Kompe- } \\
\text { tensi Menulis } \\
\text { Karya Ilmiah }\end{array}$ \\
\hline $\mathrm{Y}_{12}$ & $\begin{array}{l}\mathrm{F}_{\mathrm{o}}>\mathrm{F}_{\mathrm{t}} \\
31,543,14\end{array}$ & $\begin{array}{l}\hat{Y}=0,73+1,48 X_{1} \\
+0,24 X_{2}\end{array}$ & $\begin{array}{l}\text { Koefisien korelasi } \\
\left(\mathrm{r}_{\mathrm{y} .12}\right) \text { sebesar } 0,70 \\
\text { dengan } \mathrm{F}_{\text {tabel }} 3,14\end{array}$ & $\begin{array}{l}49,00 \% \text { ke- } \\
\text { pada Kompe- } \\
\text { tensi Menulis } \\
\text { Karya Ilmiah }\end{array}$ \\
\hline
\end{tabular}

Tabel 2 di atas menunjukkan bahwa analisis dan pengujian hipotesis ketiga hipotesis kerja yang diajukan dalam penelitian ini semuanya diterima. Hipotesis pertama menunjukkan adanya hubungan positif antara pemahaman unsur kebahasaan dan kompetensi menulis karya ilmiah. Hipotesis kedua juga menunjukkan adanya hubungan positif antara sikap terhadap bahasa Indonesia dengan kompetensi menulis karya ilmiah. Demikian juga hipotesis ketiga juga menunjukkan adanya hubungan positif antara pemahaman unsur kebahasaan dan sikap terhadap bahasa Indonesia secara bersama-sama dengan kompetensi menulis karya ilmiah.

Variabel bebas yang memberikan kontribusi lebih besar secara mandiri atas variabel terikat adalah pemahaman unsur kebahasaan sebesar 44,89\%. Pemahaman unsur kebahasaan yakni kesanggupan/ kemahiran mahasiswa dalam memahami dan menggunakan unsur-unsur kebahasaan untuk kepentingan manuangkan pikiran, ide atau gagasan serta pengalamannya ke dalam bahasa Indonesia yang baik dan benar.

Hasil tersebut selaras dengan penelitian yang dilakukan oleh Javed (2013) yang mengungkapkan bahwa unsur ke- 
bahasaan berpengaruh pada kompetensi menulis siswa. Kompetensi menulis siswa di tingkat sekolah menengah dalam bahasa Inggris dipengaruhi oleh lima besar bidang isi, yakni kata akhiran, membuat kalimat / sintaks, pemahaman, tenses atau tata bahasa dan ejaan. Penelitian ini juga menunjukkan pemahaman unsur kebahasaan juga mempengaruhi hasil tulisan karya ilmiah mahasiswa.

Peningkatan pemahaman unsur kebahasaan yang meliputi peningkatan pada tataran morfologi dan sintaksis menjadi hal yang penting karena penguasaan unsur kebahasaan yang baik tentu akan berdampak pada tulisan ilmiah yang baik pula. Ada beberapa hal yang dapat dilakukan untuk meningkatkan penguasaan unsur kebahasaan, diantaranya (1) melalui perkuliahan bahasa Indonesia dengan memeri tugas untuk mencari kesalahan-kesalahan pemakaian bahasa Indonesia yang kerap dijumpainya di lingkungan masyarakat sekitarnya untuk dijadikan pembelajaran; b) memupuk kebiasaan membaca dengan mengenalkan buku-buku bahasa Indonesia yang dapat dijadikan acuan berbahas secara baik dan benar; c) memberikan tambahan informasi atau pengayaan wawasan kebahasaan kepada para mahasiswa di luar kuliah; d) melalui pelatihan atau kursus berbahasa Indonesia yang baik dan benar.

Selain penguasaan unsur kebahasaan, sikap terhadap bahasa juga mempunyai peran penting dalam menulis karya ilmiah, sebab dengan memiliki sikap positif terhadap bahasa Indonesia, maka mahasiswa akan menggunakan bahasa Indonesia secara baik dan benar. Hal tersebut sudah barang tentu berpengaruh terhadap pemahaman tentang kaidah bahasa Indonesia yang meliputi kaidah ejaan, pembentukan kata, penyusunan paragraf, dan penataan penalaran.

Oleh karena itu, untuk meningkatkan sikap terhadap bahasa dapat dilakukan dengan berbagai upaya, antara lain; (1)
Meningkatkan kepercayaanaan diri yang tinggi kepada mahasiswa bahwa bahasa Indonesia merupakan bahasa nasional, (2) Meningkatkan rasa bangga pada diri mahasiswa untuk memiliki dan menggunakan bahasa Indonesia dalam berbagai keperluan, (3) meningkatkan perasaan senang, suka, hormat, sadar, setia, dan bangga terhadap norma-norma yang ada dan mengikat dalam bahasa Indonesia; (4) membatasi penggunaan bahasa asing oleh mahasiswa secara berlebihan; (5) meningkatkan niat serta frekuensi pembiasaan mahasiswa dalam penggunaan bahasa Indonesia di setiap kesempatan dan aktivitas, baik formal maupun non-formal; (6) mengikuti kegiatan penyuluhan bahasa.

\section{Simpulan dan Saran}

Berdasarkan hasil analisis dan simpulan pengujian hipotesis, penelitian ini menyimpulkan bahwa (1) ada hubungan antara pemahaman unsur kebahasaan dan kompetensi menulis karya ilmiah, (2) ada hubungan antara sikap terhadap bahasa Indonesia dan kompetensi menulis karya ilmiah, (3) ada hubungan antara pemahaman unsur kebahasaan dan sikap terhadap bahasa Indonesia secara bersama-sama dengan kompetensi menulis karya ilmiah.

Berdasarkan hasil tersebut, disarankan bahwa (1) dosen memberikan latihan yang berkaitan dengan unsur kebahasaan dan sikap bahasa Indonesia mahasiswa sebelum memulai perkuliahan, (2) dosen aktif menyelenggarakan kegiatan Lomba karya tulis ilmiah secara periodik dan berjenjang, (3) mahasiswa hendaknya banyak membaca buku kebahasaan dan latihan menganalisis suatu tulisan, (3) para akademisi dan peneliti melakukan pengkajian lebih lanjut tentang penelitian kompetensi menulis karya ilmiah secara lebih mendalam dan meluas dengan melibatkan variabel lain. 


\section{Daftar Pustaka}

Ahmadian, M., Hooshang Yazdani, dan Sabriyeh Ebadi. 2013. "On The Effects Of Peer Feedback And Teacher Feedback On Iranian English Language Learners, Writing Ability". International Journal of English Language and Literature Studies. Volume 2 (4). pp. 220-238.

Azwar, Saifuddin. 2013. Sikap Manusia Teori dan Pengukurannya. Yogyakarta: Pustaka Pelajar.

Chaer, Abdul dan Leonie Agustina. 2004. Sosiolinguistik: Perkenalan Awal. Jakarta: Rineka Cipta.

Djojosuroto, Kinayati. 2007. Filsafat Bahasa. Yogyakarta: Pustaka Book Publisher.

Dwiloka, Bambang, dan Rati Riana. 2005. Menulis Artikel dan Karya Ilmiah. Bandung: Rineka Cipta.

Jahin, J. Hamed. 2012. "The Effect of Peer Reviewing on Writing Apprehension and Essay Writing Ability of Prospective EFL Teachers". Australian Journal of Teacher Education. Volume 37 (11). pp. 60-84.

Javed, Muhammad. 2013. "A Study of Students'Assessment in Writing Skills of the English Language”. International Journal of Instruction. Volume 6 (2). pp. 129-144.

Murtono. 2010. Menuju Kemahiran Berbahasa Indonesia (Langkah Maju Menulis Karya Ilmiah). Surakarta: Sebelas Maret University Press.

Nurgiyantoro, Burhan. 2014. Penilaian Pembelajaran Bahasa. Yogyakarta: BPFE.

Dalman, H. 2014. Keterampilan Menulis. Jakarta: PT. Raja Grafindo Persada.

Rokhman, Fathur. 2013. Sosiolinguistik (suatu Pendekatan Pembelajaran Bahasa dalam Masyarakat Multikultural). Yogyakarta: Graha Ilmu.

Sarwono, Sarlito W. 2010. Pengantar Psikologi Umum. Jakarta: PT. Rajagrafindo Persada.

Singh, Termit Kaur Ranjit dan Saravana Kumar Rajalingam. 2012. "The Relationship of Writing Apprehension Level and Self-efficacy Beliefs on Writing Proficiency Level among Pre-university Student". English Language Teacing. Volume 5 (7). pp.42-52.

Slamet, S.T.Y. 2009. Dasar-Dasar Keterampilan Berbahasa Indonesia. Surakarta: LPP UNS dan UNS Press.

Sumarsono, dan Patarna, Paina. 2002. Sosiolinguistik. Yogyakarta: Pustaka Pelajar.

Suriamiharja, Agus, Akhlan Husein, dan Numuy Nurjanah. 2006. Menulis. Jakarta: Departemen Pendidikan Nasional.

Suwandi, Sarwiji. 2011. Penelitian Tindakan Kelas (PTK) \& Penulisan Karya Ilmiah. Surakarta: Yuma Pustaka.

Verhaar, J.W.M. 2012. Asas-asas Linguistik Umum. Yogyakarta: Gadjah Mada University Press.

Wardani, K. Devi Kalfika A., Gosong, M., Artawan, G. 2013. "Sikap Bahasa Siswa Terhadap Bahasa Indonesia: Studi Kasus di SMA Negeri 1 Singaraja". e-Journal Program Pascasarjana Universitas Pendidikan Ganesha. Volume 2 (3). pp. 14-24. 